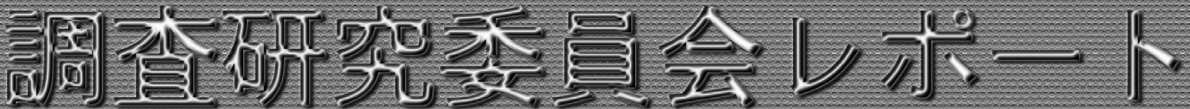

基礎・材料・共通部門技術委員会・調查専門委員会の活動内容・状況を報告する。

\section{パルス電磁エネルギーの生体作用と高度応用 調査専門委員会}

\section{1. 背景および目的}

パルス電磁エネルギーによって瞬時に生成される超高電 場, 超強磁場, 超高圧, 超高密度, 超高温, 高流束粒子ビ 一ムなどの動的な高エネルギー密度場は，極限物性研究の 他，核融合，加速器，電磁波源，材料プロセス，環境，食 品など多岐にわたりユニークな応用がある。パルス電磁エ ネルギー技術委員会（PPT）の下，「パルスパワー放電とそ の高度利用技術」（1998～2000），「パルス電磁エネルギー の発生と制御」（2002～2004）および「パルスパワー技術の 産業応用」（2005～2007）の 3 つの調查専門委員会の活動 を通して，パルス電磁エネルギーの発生・制御技術，関連 現象とその産業応用の調査が行われてきた。その中で，生 物解析技術の高度化と医工や農工連携の活発化を背景に, パルス電磁エネルギーを生物に利用する試みが盛んに行わ れている。この分野をバイオエレクトリクスと呼ぶ。生体 にパルス電磁エネルギーを用いることの特徴は，いわゆる 電気ショックとは異なり, 強大なパワーや反応性を利用し て, 非熱的に生体構造に一過性あるいは不可逆的な変化を 生じさせる点にある。場合によっては，直接作用がきっか けとなって生体二次反応が誘導される。例えば，欧米では この作用を利用した癌治療等の臨床試験が進められてい る。

本委員会は，多岐にわたるパルスパワー生成極限反応場 の生体作用とその応用に関する最先端研究を整理して体系 化し，将来の研究・開発のあり方への指針を与えることを 目的として, 2009 年 1 月〜 2011 年 12 月の 3 年間にわたり, 調查活動を行った。

\section{2. 調査対象}

（1）生体に作用させうるパルス電磁エネルギーの形態 パルス電磁エネルギーによって形成される極限反応場と して, 電場, 磁場, 衝撃波, 光, 熱, 大気圧・水中プラズ マ，粒子ビームがある。これらの生成方法，生体への作用 因子と制御性，生体への適用方法等を網羅的に調查した。

（2）生体作用

生体への直接的な作用と生体内でおこる二次反応（ス卜 レス応答）はパルス電磁エネルギーの形態ごとに様々であ る。また, 作用させる条件, 対象の種別（動物, 植物, 微 生物，種族，株），形態（細胞単体，組織，部位，個体）の 他，同株でも生育条件等によっても異なる。その中で，比 較的研究例が多いパルス電界, 大気圧プラズマ, 水中プラ ズマ，衝撃波，紫外線を中心に取り上げ，これらに対する 微生物や動物細胞の細胞死条件，形態的応答，細胞内反応
(ストレス応答)，増殖活性などを調査した。また，動物実 験や臨床試験等を通して個体における生体応答を調查し た。植物・菌糸類についても, 複数の植種や株についてパ ルスに対する様々な生体応答を調査した。

（3）応用技術

最近，パルスパワーやプラズマ等の極限反応場を身近で 容易に利用できるようになり，その応用研究が隆盛を極め ている。例えば，パルス電界については，エレクトロポレ ーションとして知られる細胞膜開孔現象に加え, ストレス 反応に基づく新しい生体作用が見出され, 医療, 美容, 農 業, 食品分野への応用が期待されている。また, プラズマ ジェットの登場によって, 遺伝子導入等のバイオ技術, 医 療，殺菌，植物成長制御等にプラズマが利用されつつある。 衝撃波など他の反応場の応用も進んでおり，これらを網羅 的に調查した。

\section{3. 活動内容と成果}

3 年間の活動において, 調查専門員委員会 4 回, 全国大会 におけるシンポジウム 1 回， $\mathrm{A}$ 部門大会テーマ付きセッシ ヨン企画 2 回, 単独シンポジウム 2 回 (2012 年に 1 回予定) を開催した。成果報告として，2012 年 9 月にバイオエレク トリクス国際シンポジウムを開催し, 国内外の先端研究を 取りまとめる。また, 平成 25 年 2 月発行予定の電気学会論 文誌 $\mathrm{A}$ 特集号「パルスパワーの生体作用と医・農・水・環 境への先進応用」において, 本活動で得られた成果を総括 する。

\section{4. 今後の展開}

パルスパワーは, 概して生体に対する新規の物理刺激（ス トレス）である。この直接作用とともに，生体二次反応を 上手く利用できれば，さらに多くの応用が拓ける。一方で， 安全性評価は欠かせない。今後も注目したい。

委員長 勝木 淳

\footnotetext{
委員 長 勝木 淳 (能本大)

委員 伊藤昌文 (名城大), 猪原 哲 (佐賀大) 内田 諭（首都大学東京），金子俊郎（東北大） 國友新太 (荏原総合研究所), 江 偉華（長岡技科大） 佐藤正之 (群馬大), 清水尚博 (日本ガイシ) 下村直行（徳島大），末廣純也（九州大） 瀬田玄道（サントリービジネスエキスパート），高木浩一（岩手大） 永津雅章 (静岡大), 真島隆司 (IHI) 森田一二夫（東京インスツルメンツ）

幹事 南谷靖史 (山形大)

幹 事 補 浪平隆男 (熊本大)
}

委員会構成メンバ 